\title{
On The Problem of Communication in a Transmedia Sense in Constant Reference to Its Online Determination
}

\author{
Prof. Filippo Silvestri \\ Professore Associato di Filosofia e Teoria dei Linguaggi \\ Università degli Studi di Bari "Aldo Moro" Italia \\ Dipartimento di Scienze della Formazione, Psicologia \\ Comunicazione
}

\begin{abstract}
The new world of online communication is far beyond the classical coordinates upon which the semiotic community was founded: new forms of participation establish who is inside, who is outside the new orders of discourse, while the same "author function" changes, because it is no longer a matter of a single person, but it more and more often concerns the entire communities of speakers, writers, communicators. In the light of this new scenario that is both semiotic and anthropological, it is not possible to take an apocalyptic or integrated stance: we must keep up with our own times, something can also result in accepting a world that is entirely made up of simulacra, in which new tribal forms are insinuated, along with new forms of barbarism as well as of orality intertwined with new ways of writing. From Castells to Levy, Maffesoli, de Kerckhove, the new philosophy of language must question the limits and conditions of the new ways of contemporary online communication, perhaps in order to discover new collective forms of unconscious in the big data network.
\end{abstract}

Keywords: Internet, Comunication, Network Society, Real, Virtual.

The issue of communication in a transmedia sense is determined by innumerable factors. An exhaustive review would imply a monographic work, which would soon be out of date, given the speed with which things change. Moreover, the panorama is made even more complex by a series of transmedia circumstances at a phenomenological level corresponding to a set of media syntheses, which guide the experience of things. This being the case, we will limit ourselves here to some considerations in constant reference to the problem of the relationships between online individuals, with particular attention to the semiotic implications that these relationships can have.

And yet, though the field of analysis has been restricted to this variable, the problem remains difficult to manage, so theoretical choices are fundamental for an analysis that is at least partially effective. The anthropological scenario is, in fact, articulated by a series of intersecting variables, which often escape in directions that may only be treated in a multidisciplinary way. Among these, attention should be paid to the degree of participation of those who are involved in the various dynamics of being on the net, in a semiotic, linguistic and cognitive sense, supporting all the possible meanings that the expression may imply. The new Kantian subject as protagonist of the new mass-media criticism has the measure of his capacity to be in the world starting from his own concrete multimodal participation in the communicative and meaningful dialectic, i.e. his predisposition to know how to manage the ways of access to the mass media world that interests him. Here we are concerned with his speed in managing the modes of communication in a political framework that remains largely variegated, if we understand the communicative relationship as always determined by its inclusion in particular dynamics that unfold in constant reference to a neoliberal logic typical of the market, which is only partially mitigated by a democratic regulation and guaranteed in this sense by the different state institutions, to the extent in which they are able to establish a participatory balance.

In the light of this, expressions such as 'mass society', 'mass communication' need to be revisited in connection to their metaphorical sense, faced with an anthropological whole dominated by a substantial fragmentation of interests, to which so many niche markets correspond. This fragmentation is able to accommodate the differential multiplication of the demand: assuming an almost universal communication channel (the network), the contents flowing through it are differently arranged to meet the demand for meaning that is proposed every time. The person acting in this sphere of communication is no longer the citizen, nor is it the worker, as it belongs to the new category of producer-consumer of information/signification; it is therefore a person animated by an active role in the communication process who acts from time to time by virtue of the choices he makes. Hence, different degrees of social cohesion ensue, as well as modes of coherence in the semiotic construction of texts, which vary according to the interests at stake. 
We must then keep in mind that given the new context of communication, the very concept of authorship has profoundly turned within a network of relationships-communications where a growing "agentivity" can be witnessed, reflecting a different participation in the construction of the messages, according to ways that are global and local at the same time, all starting from a source of communication-signification that is mobile and therefore potentially, virtually ubiquitous. The Cartesian subject, protagonist of modern communication must be questioned since its feature significant productivity, productivity by composite characters, defined in a framework characterised by some dissolution of the canonical boundaries of signification.

Here there is still a necessary step which has to be taken in the present analysis: the authorial-authoritative subject is no longer single but plural and as such it is differentiated in its interior as a result of an online collection that is organised around common interests which are however different and from the similarly common and yet different choices that follow. The text that corresponds to this plural subject is marked by a continuous change/modification that casts doubt on the classic criteria establishing the responsible reliability of what we read/write, in an increasingly complex reference framework as it is characterised by a continuous narratological intersection of what is real with what is otherwise virtual. All is well regarded because of its characteristic instability and impermanence, a reflection of a movable type of new mass media and even in view of the continuing technological transformation that these media know, which entails a certain social fragmentation, the expression of those same means of communication, which in turn could guarantee a possible solution/convergence.

In a classic way the framework in which multimodal communication is realised is now marked by different phenomenological forms of attention, which are contextual and formed in alternation and in an equal number of interest framing processes, which is sensitive as such to a different set of electronic stimuli. Multimodal communication is then configured in the same way as a process characterised by a certain 'generative force', which relies on a mass of semiotic resources brought into play and functionalised in a continuous transformation of modes of representation, with all the necessary adjustments. The semiotic work is the result of a selection and a transformation of the available material on the basis of interpreting process negotiation, which is carried out in a continuous recovery marked by power relationships of "uses and gratifications". Every emotion is thus governed because it is reduced to prefabricated models (therefore controlled), where everything is transparent due to the reduction to a single, uniforming (unanimous) thesis: every phenomenon is read in its capacity as a commodity and as such represented by an advertising system, the latter being understood as a new metropolitan ethos, due to an anonymous catechism, an 'uninterrupted cosmic litany', a new and unique ordering principle ${ }^{2}$.

The multimedia scenario that is designed is thus always halfway between order and disorder, disaggregation and aggregation, favouring a dialectical elastic band in constant motion. From a semiotic (and economic) point of view, the above is determined in a dual direction: on the one hand, there is a tendency to achieve convergence and integration through a single medium, and on the other there is a multiplication of supports (laptops, mp3 readers, cell phones, pay TV), without prejudice to the game of Chinese boxes for which each medium is in turn the content of the medium that surpasses it. The theoretical battle that is fought in this way is useful for the understanding of the new means of communication, and sees opposing categories such as interactivity, multimedia, virtuality soon overcome by those with a foundational character as numerical representation, modularity, automation, variability and transcoding ${ }^{3}$. Beyond these theoretical distinctions, a strong individualisation is still visible on the anthropological level configured in close relationship with the daily use of the different personal media, to which an open set of new forms of aggregation corresponds; such forms of aggregation are in turn expressions of as many modes of collectivity (Levy), of connectivity (de Kerckhove) that are often grafted onto medium-range relationships from a geographical point of view; these are linked to the different forms of virtual communities which are consequently possible.

Specifically, Manuel Castells, ${ }^{4}$ etwork society is based on a new balance which is characterised by the same number of load-bearing structures at an institutional level, attributable to broad categories such as information, flexible production, reticular logic, the pervasive diffusion of technologies, their convergence. The network society is "una società, cioè, che si sposta dall'impostazione sostanzialmente verticale delle burocrazie che hanno governato per millenni - eserciti, Stati, grandi aziende - per andare invece verso un'organizzazione a rete. Questo, però non vuol dire che le organizzazioni diventato necessariamente «buone»:

\footnotetext{
${ }^{1}$ Cfr. G. Kress, Multimodalità. Un approccio sociosemiotico alla comunicazione contemporanea, Progedit, Bari, 2015 , p. 47.

${ }^{2}$ Cfr. E. Coccia, Il bene delle cose, Il Mulino, Bologna, 2014, pp. 28 e 52-53.

${ }^{3}$ L. Manovich, The Language of New Media, The MIT press,Cambridge, Massachusetts; London, 2001; trad. it. Illinguaggio dei nuovi media, Olivares, Milano 2002, pp. 46-71.

${ }^{4}$ M. Castells, The rise of the network society, Blackwell, Oxford, 1996; trad. it.La nascita della società in rete, Università Bocconi Editore, Milan 2002. 
Se gli obiettivi di una società sono negativi, un'azienda organizzata in reti produrrà in modo più efficiente questi obiettivi negativi. Quello che cambia, insomma, è la forma di produzione"s ("i.e. a society that moves from the substantially vertical approach of the bureaucracies that have governed for millennia - armies, states, large companies to move towards a network organisation. This, however, does not mean that organisations necessarily become "good": if a company's goals are negative, a networked company will produce these negative goals more efficiently. In short, what changes is the form of production", our translation). The network society therefore does not know vertical models of domination since it develops in a horizontal network, where "inclusione ed esclusione costituiscono i nuovi parametri vitali", ("inclusion and exclusion are the new vital parameters", our translation). Provided the same communication codes, "le reti sono strutture aperte, capaci di espandersi senza limiti, integrando i nuovi nodi", ("networks are open structures, capable of expanding without limits, integrating new nodes", our translation), given that the real holders of power are those who continue to have the possibility of turning on and off in an algorithmic way the switches that connect the network.

Over the years, the new media have acquired a pivotal role in the determination of power relations, with all its implications from a social point of view, as in the area of production relations, according to guidelines that are ever more clearly dealing with variables related to the so-called 'immaterial work'. It is worth once again remembering how all of this is accomplished within the framework of a globalisation of cultural flows, to which follows the contextual countermelody "recupero delle identità forti, legate al territorio e alla tradizione, più che sul loro lineare superamento ad opera delle narrazioni deboli" ("recovery of strong identities linked to the territory and tradition, rather than their linear overcoming due to weak narratives", our translation). Castells writes, "The unit is the network", that is the unit of measurement of the world on an experiential level; it is the network - a network which, due to its diffusion, determines as its institutional counterpart a work that becomes wage-wise and opens in this way to the advent of a world, which retains a possibility of free development also because of a social disaggregation as its most important sociological counterpart. On an overall level considered to be of an aesthetic nature, there is a characterisation of the experience that goes through a continuous simulation, because the whole communication system seems to be planted on a virtual ground, for which "la stessa realtà è interamente catturata, completamente immersa in un ambiente virtuale di immagini, nel mondo della finzione, in cui le apparenze [...] divengono esperienza" ("the same reality is entirely captured, completely immersed in a virtual environment of images, in the world of fiction, in which appearances [...] become experience", our translation). In this new ontological/aesthetic horizon paradoxically the 'mass' disappears, if it is understood as a constitutive mass media vector, to the advantage of a certain individualistic personalism, which plays its own destiny because of the interests that guide it in the choice/discovery of its own affinities, without the prevalence of reasons attributable to a shared rationality, without the new forms of aggregation effectively implying a real solidarity between those who converge in this way: we are like in front of differential identities (Foucault) that are inside, that are outside the mass media network of relations, while it no longer matters to govern everything from above, as if we were still in a pyramid-type arrangement of relations. What continues to preserve a value are the processes of production and exchange of information, remaining on the one hand on the level of the governance of things a certain definition of elitist environment and on the other a corresponding disintegration, disorganisation of the common civil life. With Castells: "le élite sono cosmopolite, il popolo è locale. Lo spazio del potere e della ricchezza si proietta in tutto il mondo, mentre la vita e l'esperienza della gente comune è radicata nei luoghi, nella propria cultura, nella propria storia" ("The elites are cosmopolitan, the people are local. The space of power and wealth is projected throughout the world, whereas the life and experience of ordinary people is rooted in places, in their own culture, in their own history", our translation). The reality of relationships remains so distinct in at least two fronts: the one affected by the technological changes of communication and information and what remains on the other hand outside, as a social field that once excluded, 'resists' in various ways precisely in order not to be eradicated from its characteristic anthropological determination. The network society "può includere a prescindere dalla distanza ma anche escludere malgrado la prossimità geografica, in quella doppia logica, appunto di inclusione ed esclusione, che è la grammatica elementare della rete" 11

\footnotetext{
5 Intervista al sito www.mediamente.rai.it/articoli/20020530b.asp, in A. Abruzzese, P. Mancini, Sociologie della comunicazione, Laterza, Rome-Bari, 2007, p. 255.

${ }^{6}$ Ibidem.

${ }^{7}$ M. Castells, La nascita della società in rete, cit. p. 537.

${ }^{8}$ A. Abruzzese, P. Mancini, cited work, p. 256; cfr. M. Castells, The Power of Identity, Blackwell, Oxford, 1997; trad. it. Il potere delle identità, Università Bocconi Editore, Milan 2003, pp. 5-75.

${ }_{9}^{9}$ M. Castells, La nascita della società in rete, cit., p. 431.

${ }^{10}$ Ivi, p. 476.

${ }^{11}$ A. Abruzzese, P. Mancini, Sociologie della comunicazione, cit., p. 264.
} 
("may include regardless of distance but also exclude despite the geographical proximity, in that double logic, precisely of inclusion and exclusion, which is the elementary grammar of the network, our translation) ${ }^{12}$ and best represents the current structure assumed by the Empire.

In this game of inclusions and exclusions, the language that is used on the net represents a discriminating factor for those who cannot keep up with it, behind the speed of its composition, directly proportional to the abbreviation of its formulas, with implications on the cognitive level that the thing implies, all more or less responsive to the principle of minimum effort and a certain miniaturisation of online languages: the speed of writing on the net brings it closer to the spoken language, favouring a synthesis of orality and writing that leads towards a Creole form marked by dialogical, pictographic, visual, even gestural elements, if only the whole rose of emoticons is considered ${ }^{13}$. The parameters of network communication are inscribed within a new equilibrium between sender and receiver, an equilibrium characterised by the disposition to an exchange that is not unidirectional and that states that all the actors of communication are included in relations of interdependence, direct expression of a current of signification crossed by new metaphors, therefore by new forms of imagination and by new ways of semiotic bricolage, with all the evocative magic character involved: the parole invests the langue with its characteristic force, which belongs to a dialogue that takes place on the net and that is formed between people who are each time the characters of a self-narration. Precisely the construction of the characters on the net is slow and gradual and implies a concomitant tendency to 'recite' because anyone who moves online, regardless of the context they go through, is always part of a 'staging'. The scripts in play, with the different degrees of success that they imply, revolve around as many negotiation processes, which are closely related to all the dynamics / dialectics of relationships, passing between what is real and what is hyperreal / virtual, because it is traversed by simulative quotas: the language that is spoken, that is written, knows high shares of admixture with that of advertising, with constant attention to the poetic side of the altogether rhetorical mass. The simulative quotas, simulacrals of the same language grow exponentially, with all the semantic implications of the case, dictating in this way new forms of linguistic competence. From a psychological-cognitive point of view, the language of new media is permeated by persuasive elements, which are intertwined with an open series of anxieties and stress being the constituent reflection of a new narcissism of the network: we are all consumers of meaning and as such homogenised on the semiotic level in a linguistic universe, which is determined by a network of prevailing brands ${ }^{14}$, put together working in depth on the poetic-emotional side of the relationship with the other. The semiotic issue is thus constituted along a multimodal axis of communication, whereby all the semantic paths are defined starting from a hypertextual and interactive network, which extends from the Web to all other places of contemporary communication, in a holistic whole in which there is a global empire of signification, more and more calibrated on the constitution of writing starting from a screen, of what dimension we want, following in the way of proceeding an algorithmic tree of semantic relations. On these logical schemes of signification, new lingua francas that inhabit the Web are supported in different degrees by osmotic and convergent relationships between the source languages, with a game of labelling functional to the simplification of communication due to its expansive mechanisms, which are always involved in an adaptive horizon of considerations ${ }^{15}$, without any moral panic ${ }^{16}$ which can occur due to a continuous technological innovation, all these problems of media-morphosis, almost always combined with principles of minimum effort, so that the more frequently an expression is used, the more likely it is destined to be abbreviated (Zipf's law). Any consideration made so far must obviously be understood in an entropic manner. Danesi: "Quindi, il Principio del Minimo Sforzo riflette non solo tendenze biologiche inerenti all'entropia di sistemi comunicativi, ma anche e soprattutto "risposte" comportamentali a nuove esigenze sociologiche e psico-comunicative. Visto l'emergere di una nuova oralità nel cyberspazio, questa tendenza riduttiva permette di scrivere con rapidità simulando il ritmo del parlato. La parola concisa ha quindi un valore sociale ed emotivo assai alto, nel senso jakobsoniano""17 ("Hence, the Principle of Minimum Effort reflects not only biological tendencies inherent in the entropy of communication systems, but also and above all behavioural "responses" to new sociological and psycho-communicative needs. Given the emergence of a new orality in cyberspace, this reductive trend allows one to write quickly by simulating the rhythm of speech. The concise word therefore has a very high social and emotional value, in a Jakobsonian sense", our translation).

\footnotetext{
${ }^{12}$ Cfr. M. Hardt, A. Negri,Empire, Harvard university press, London, 2000; trad. it.Impero, Rizzoli, Milan, 2001.

${ }^{13}$ Cfr. M. Danesi, La comunicazione al tempo di internet, Progedit, Bari, 2013.

${ }^{14}$ Cfr. N. Klein, No Logo: Taking Aim at the Brand Bullies, Alfred A. Knopf, Toronto, 2000.

${ }^{15}$ R. Fidler, Mediamorfosi. Comprendere i nuovi media, Guerini e Associati, Milan, 2002.

${ }^{16}$ S. Cohen, Folk Devils and Moral Panics: The Creation of Mods and Rockers, MacGibbon and Kee, London, 1972.

${ }^{17}$ M. Danesi, La comunicazione al tempo di internet, cit., p. 86. 
All things considered and in this way overcoming what are strictly linguistic aspects, the Web is (on an evolutionary line) a means that confirms, like the others that preceded it, a tendency to flexibility and to different technological adaptation - something that takes nothing away from a certain "informative bewilderment", which reigns supreme because of the multiple openings that have been made possible - a loss that must be managed, not putting the blame on those who know better than others the world of online relationships, with all the real-hyper-virtual character that it entails, perhaps by asserting the myth of an alleged "harmonious local community". Likewise, the game of building identities on the net should not be overly dramatised, because this circumstance probably has high quotas in adolescence, but it does not represent a far-reaching phenomenon if looked at as a whole, because online life is mostly functional to aspects that are very present in real life: the web remains "un'estensione della vita così com'è, in tutte le sue dimensioni e con tutte le sue modalità"18 ("An extension of life as it is, in all its dimensions and with all its modalities", ourtranslation), an extension obviously to calibrate on the new distances that the communication on the net entails and on the different "thresholds of use" that every form of communication implies, together with its inevitable reflections on the type of sociality that one lives. And therefore, the principle that every communication technology is itself an extension of the previous (which it contains) would require the review of a series of platitudes claiming that there has been in recent years a clear anthropological variation in the way of understanding community living. To simplify things, it cannot be denied how in the contemporary sense the network has fuelled the so-called "communities of choice", but the freedom which everyone enjoys is not constituted exclusively online, but rather is based specifically on the dynamics of real communication, as understood in the classical way by mass media studies (Innis, McLuhan): from the internautic network to the road that we inhabit the dialectic and semiotic elastic cannot favour any point of tension, either real or virtual. So if today (and not since yesterday) communities certainly have a "personalised" character, this circumstance is again attributable only to the Web and if it also represents a certain individualism, this must be linked with other available part in a certain 'sincerity' in the staging of one's person (on the net), in order to avoid what is ultimately not desired. Castells: "[...] su Internet è meglio che vi assicuriate che tutti sappiano che siete un cane, e non un gatto, o vi ritroverete immersi nel mondo intimo dei gatti. Perché su Internet siete quello che dite di essere. Ed è su questo che una rete di interazione sociale viene costruita nel corso del tempo"19 ([...] on the Internet it is better to make sure that everyone knows that you are a dog, and not a cat, or else you will find yourself immersed in the intimate world of cats. Because on the Internet you are what you say you are. And it is precisely on this that a network of social interaction is built over time", our translation).

From a political point of view, one of the decisive junctions that seems to emerge in the new network of international relations also has a semiotic connotation, which can be summarised, remembering how real and virtual / hyperreal are to be always considered in a scale relationship, for which given a global representation channel, each (political) act must be as large / resonant as the way of communication that is chosen as the means to represent what is done. If the medium is universal, the political gesture must rise to a height, to the point of assuming 'symbolic' garments proportionate to the means of communication that one wants to be a sounding board. Castells: "Le funzioni nelle reti globali guadagnano un potere sempre maggiore che bypassa ampiamente le istituzioni dello stato-nazione. Così, i movimenti si trovano di fronte alla necessità di fornire una risposta che sia all'altezza della portata globale dei poteri costituiti, attraverso azioni simboliche che provocano un impatto globale sui media" 20 "Functions in global networks gain ever greater power which largely bypasses the nation-state institutions. Hence, the movements are faced with the need to provide an answer that is up to the global reach of the established powers, through symbolic actions that cause a global impact on the media", our translation). Once again the winning combination seems to respond almost to an oxymoron, because it combines both local and global, real and virtual. Castells: "[...] i movimenti sociali più influenti sono, allo stesso tempo, radicati nel loro contesto locale e rivolti verso un impatto globale"21 ("[...] the most influential social movements are, at the same time, rooted in their local context and turned towards a global impact", our translation). Obviously the political framework is made more complex by a different articulation of the relationships in the network; if these appear to be inspired by democratic motifs of participation that are horizontal, they are however realised in the shadow of a technological power that remains a privilege of those who know how to make the network work, by exclusively arranging algebraic keys, which are not within everyone's reach (keeping in mind how this elite is in any case at the service of those who continue to govern the different course of things in a classical way because it is capitalistic).

\footnotetext{
${ }^{18}$ M. Castells, The Internet galaxy : reflections on the Internet, business and society, Oxford university press, Oxford, 2001; trad. it. Galassia Internet, Feltrinelli, Milan, 2006, p. 119.

${ }^{19}$ Ivi, pp. 128-9.

${ }^{20}$ Ivi, p. 138.

${ }^{21}$ Ibidem.
} 
Once again, considering the issue of politics from a political point of view, it is necessary to agree with Lévy ${ }^{22}$ upon the fact that we are in the midst of a progressive development, which outlines plans of action and cognition that are characterised by a considerable extension of dimensions such as space, meaning and freedom, which in turn imply new ways of taking responsibility on the ethical side with respect to what happens to us. The democratic plan on which Lévy reasons is thus combined, taking into account an inseparable synthesis of communication and freedom, with all that it entails in terms of human rights, which can no longer be denied. The ways of contemporary communication make the unknown visible and known, thus contributing to broaden the idea of freedom and the right to it, which is no longer limited to political considerations: "Più comunicazione implicherà più libertà: nel prossimo secolo non sarà solo il cyberspazio a diffondersi, ma anche la cyberdemocrazia"23 ("More communication will imply more freedom: in the next centurynot only will cyberspace spread, but also cyber-democracy", our translation). What we live in today is the "civilisation of real-time", a civilisation of communication, information, of a thought that traveling at such a speed as to make any form of representation always inadequate, as it is always late in its being continuously exceeded. The political dialectic of relationships that hold us together is challenged every time. We are moving into a new "public space" formed by the networking of computers, a space where the conditions of government change regularly (in a broad sense) and where there are always new political scenarios which are unpredictable. The governance of things is organised around new virtual communities characterised by different constitutive structures, reflected in a political sense of transparency, which is directly proportional to the growth of information and communication that marches at an exponential speed, an expression of new forms of interconnection and interdependence never known before. Science, technique, money and media are the vectors of a progressive deterritorialisation (Deleuze, Guattari) a reflection of a new freedom of expression. We are with Lévy on the road to a process in which "ogni documento o segno prodotto dalla scienza umana farà virtualmente parte di un solo ed unico ipertesto planetario" "24 ("Every document or sign produced by human science will virtually be part of a single and unique planetary hypertext", our translation). Beyond any apocalyptic pessimism, the guiding idea of an evolutionary nature is that there is a relationship of continuous conjunction of freedom, creativity and democracy, in the name and on the basis of an intelligence that is inevitably collective. This being the case, given certain assumptions, a network without mediators is possible, without deputy representatives, according to a way of understanding the relationship on the network characterised by a playful pleasure that is participation, which corresponds to a proliferation of the sense of power of every single person involved. Here in the network the communities retain an elective character, despite having a nebulous structure: their constitutive force is connective and guarantees a safeguard to the individual, who knows how to feed on the imaginary he encounters. Nowadays we are witnessing a dissemination of meaning that knows no guardians, in a continuous interweaving of material and immaterial, which as such comes from below and belongs to a precise relational aesthetic. The molecular, fluid and connective structure of the digital language that is spoken excludes the possibility of great narratives: rather, a certain proletarianisation of public experience which moves together towards a creative disorder and plays in favour of a horizontal connection of the multitudes is worthwhile, as long as it goes hand in hand with a push towards secularisation and disenchantment within the framework of a more general affective and fluid spontaneity. The fluidity of the relations we have alluded to is characteristic of a widespread international nomadism (Deleuze, Guattari), which calls into question a life lived in the name of a research that is jouissance (Lacan).

Beyond those that are and remain contingent manifestations, today we are witnessing a dissolution of politics or politics understood in a classical (modern) way, while the democracy of relations is measured starting from the statutes established in a transversal way by digital languages. The social body generally understood appears as an open laboratory, where the interpreters of new media are born and develop: the skin of our culture is a technological skin $^{25}$, which covers a body crossed by a certain presentism often devoted to consumerism, in turn an expression of a new individualism, which knows no centres of determination, always chasing new playful solutions, new forms of a will to power otherwise acquired compared to the classic way. In a framework so delineated, both the politician and the intellectual tend to disappear, submerged by new orders of discourse that refer to an immediate sociality, in which forms of protagonism emerge that have nothing more than representative politics.

\footnotetext{
${ }^{22}$ P. Lévy, Cyberdemocratie : essai de philosophie politique,Editions Odile Jacob, Paris, 2002; trad. it. Cyberdemocrazia, Mimesis, Milan, 2008.

${ }^{23}$ Ivi, p. 28.

${ }^{24}$ Ivi, p. 34.

${ }^{25}$ Cfr. D. de Kerckhove, The skin of culture : investigating the new electronic reality, Kogan Page, London, 1997; trad. it.La pelle della cultura. Un'indagine sulla nuova realtà elettronica, Costa \& Nolan, Ancona, 2000. 
The new barbarians are coming forward ${ }^{26}$, moved by an emotional, affective participation as liquid as their internautic statute, marked by a tendency to desecration, demystification, the desymbolisation of many otherwise inherited practices. Life is lived through video-spheres, navigating visually among the different bubbles of the network.

Given certain premises, then a horizontality of symbolic and emotional relationships is valid, while at least at certain levels some identity connotations fade away, a widespread anonymity being worth at least on the net: the communications are transpolitical and are in many ways invisible because they are based on different imaginaries, which are as such at least partly imperceptible, ethereal, while arising from the belly of a social, which shares nothing with certain alleged avant-gardes of contemporary hermeneutics / aesthetics ${ }^{27}$. Here in the network as elsewhere and as we have already reported, there are no great narratives to follow, but rather many small things to share. The neotribalcommunities $^{28}$ that consequently emerge, arise from a lack of structural and social order, a provision which corresponds to the fluctuation through the circulators nodes of communication flows, in which new forms of reputation apply, new ways of elective affinity constitution. In this new horizon of online relationships special gift economies are established, all because of an emotional engagement in communities that offer networking to those who follow their own erratic impulses: the root that follows is always dynamic and the creative forms that are admitted all have a connective characterwhich leads to an us that is fluid and elastic.

Admitting that things are they way they are being described here, those that emerge are new forms of desire with a degree of secrecy, which leads everyone to hide in the crevices of a microphysics(Foucault) of political divisions. The transfiguration of the political and its contextual implosion are fulfilled in a horizon of relationships that often have a playful character, that lives on the echo of a widespread spectacularisation: beyond every possible form of surveillance there is a cultural tingling, where a logic connected to a whole series of ways of communication which are coordination and not communication reigns supreme. The screens of our media are the new skin that we inhabit in all their immediacy: here for us consequently stands a substantially dispersed creativity ${ }^{29}$ and always here (in the net) and everywhere as its reflection, there is a certain tendency to be invisible, to masking as the effect of a general deterritorialisation, without this masking, this invisible living, contradicting a certain transparency, which no longer admits opacity in the management of power, if understood in a classical way. The epochal transition that takes place in many fields of the online relationship is therefore from the law of the State to that of the group to which it belongs, where principles attributable to an effort that would be of "resistance" are not valid, but rather represent a new tendency to recreation.

These are then the days that radically belong to a continuous emotional seduction and that if put together, give rise to a new neo-baroque era. The electrified language is proper of a collective and connective pulsating nervous system, in turn part of a new psychotechnology, of a new biotechnology, which redesigns the boundaries of our intimate feeling. Today language is everywhere, tuned as it is into an electronic orality at the service of new industries of consciousness. Pinocchio 3.0 is an inorganic puppet filled with collective contents and shared connective processes, it is a dematerialised being, because it is now made up of just bits and as many big data, which listen to and penetrate our most secret recesses. The marriage between computer and telephone is realised in the complex horizon of a widespread hypertextual sharing, where an authentic dictatorship of transparency prevails. What is observed is a widespread tendency to movement, from which follows an ethical discourse of difficult articulation, because it is linked to a principle of responsibility that hinges on a planetary extension. The aesthetic picture thus delineated is marked by a step, which in turn leads to a progressive abandonment of its intentional con-sequentiality, for a fragmented living connected to the network, which on a symbolic level has a lot to do with a collective unconscious all deposited in big data. Our identities, our memory, appear as such externalised and continually re-discussed in a public horizon of determination.

\footnotetext{
${ }^{26}$ Cfr. A. Abruzzese, Il crepuscolo dei barbari, Bevivino Editore, Milan/Rome 2011.

${ }^{27}$ Cfr. D. de Kerckhove, V. Susca, Transpolitica. Nuovi rapporti di potere e di sapere, Apogeo, Milan, 2008.

${ }^{28}$ Cfr. M. Maffesoli, Le temps des tribus : le déclin de l'individualisme dans les sociétés de masse, Meridiens Klincksieck, Paris, 1988 ; trad. it.Iltempo delle tribù. Il declino dell'individualismo nelle società postmoderne, Angelo Guerini e Associati, Milan, 2004.
} 


\section{Bibliography}

Abruzzese A.,Il crepuscolo dei barbari, Bevivino Editore, Milan/Rome 2011.

Castells M., The rise of the network society, Blackwell, Oxford, 1996; trad. it.La nascita della società in rete, Università Bocconi Editore, Milan 2002.

-,The Power of Identity, Blackwell, Oxford, 1997; trad. it. Il potere delle identità, Università Bocconi Editore, Milan 2003.

-The Internet galaxy : reflections on the Internet, business and society, Oxford university press, Oxford, 2001; trad. it. Galassia Internet, Feltrinelli, Milan, 2006.

Coccia E., Il bene delle cose, Il Mulino, Bologna, 2014.

Cohen S., Folk Devils and Moral Panics: The Creation of Mods and Rockers, MacGibbon and Kee, London, 1972.

Danesi M., La comunicazione al tempo di internet, Progedit, Bari, 2013.

de Kerckhove D., The skin of culture : investigating the new electronic reality, Kogan Page, London, 1997; trad. it.La pelle della cultura. Un'indagine sulla nuova realtà elettronica, Costa \& Nolan, Ancona, 2000.

de Kerckhove D., Susca V., Transpolitica. Nuovi rapporti di potere e di sapere, Apogeo, Milan, 2008.

Fidler R., Mediamorfosi. Comprendere i nuovi media, Guerini e Associati, Milan, 2002.

Hardt M., Negri A., Empire, Harvard university press, London, 2000; trad. it. Impero, Rizzoli, Milan, 2001.

Klein M., No Logo: Taking Aim at the Brand Bullies, Alfred A. Knopf, Toronto, 2000.

Kress G., Multimodalità. Un approccio sociosemiotico alla comunicazione contemporanea, Progedit, Bari, 2015.

Lévy P., Cyberdemocratie : essai de philosophie politique,Editions Odile Jacob, Paris, 2002; trad. it. Cyberdemocrazia, Mimesis, Milan, 2008.

Maffesoli M., Le temps des tribus : le déclin de l'individualisme dans les sociétés de masse , Meridiens Klincksieck, Paris, 1988 ; trad. it.Iltempo delle tribù. Il declino dell'individualismo nelle società postmoderne, Angelo Guerini e Associati, Milan, 2004

Manovich L., The Language of New Media, The MIT press, Cambridge, Massachusetts; London, 2001; trad. it. Illinguaggio dei nuovi media, Olivares, Milano 2002. 